\title{
Social representations of child and adolescent sexual abuse: A study of juridical professionals
}

\author{
Representações Sociais sobre o abuso sexual infantojuvenil: \\ um estudo com profissionais jurídicos
}

\author{
Camila de Alencar PEREIRA ${ }^{1}$ iD 0000-0002-8136-5399 \\ Silvana Carneiro MACIEL2 ${ }^{2}$ D 0000-0003-1489-1126 \\ Dayse Barbosa SILVA ${ }^{3}$ iD 0000-0002-3005-155X \\ Luã Medeiros Fernandes de MELO3 ${ }^{3}$ (D) 0000-0001-7353-1441
}

\begin{abstract}
This study sought to identify the structure of legal professionals' representations of child and adolescent sexual abuse anchored by the central core theory of social representations. The sample included 31 professionals responsible for implementing public policies in relation to victims, their family members, and aggressors. A sociodemographic questionnaire was employed with a free word association task. The resulting data were analyzed using Statistical Package for the Social Sciences 21.0 and the R Interface for Multidimensional Analyses of Texts and Questionnaires, respectively. The central core of the professionals' representations included the terms "violence" " trauma", and "grief"; furthermore, they pathologized the abuser, and their representations were anchored by criminological and psychological explanations of sexual abuse. This fragmented view of sexual abuse lacks macroexplanations that address cultural and social factors as well as proposals that involve society as a whole.
\end{abstract}

Keywords: Adolescent; Child; Sexual abuse; Social representation.

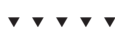

1 Universidade Federal da Paraíba, Centro de Ciências Humanas, Letras e Artes, Programa de Pós-Graduação em Psicologia Social. R. Cidade Universitária, s/n., Castelo Branco III, 58051-085, João Pessoa, PB, Brasil. Correspondência para/Correspondence to: C.A. PEREIRA. E-mail: <camila_alencarpereira@hotmail.com>.

2 Universidade Federal da Paraíba, Centro de Ciências Humanas, Letras e Artes, Departamento de Psicologia. João Pessoa, PB, Brasil.

${ }^{3}$ Universidade Federal da Paraíba, Centro de Ciências Humanas, Letras e Artes, Curso de Psicologia. João Pessoa, PB, Brasil.

Support: Conselho Nacional de Desenvolvimento Científico e Tecnológico (National Council for Scientific and Technological Development), Master's scholarship, and PIBIC scholarship.

Article based on the dissertation by C.A. PEREIRA, entitled "Representações Sociais sobre o abuso sexual infantojuvenil: um estudo com juízes e profissionais psicossociais". Universidade Federal da Paraíba, 2017.

Como citar este artigo/How to cite this article

Pereira, C. A., Maciel, S. C., Silva, D. B., Melo, L. M. F. (2019). Social representations of child and adolescent sexual abuse: A study of juridical professionals. Estudos de Psicologia (Campinas), 36, e180085. http://dx.doi.org/10.1590/1982-0275201936e180085 


\section{Resumo}

O estudo objetivou identificar a estrutura da representação dos profissionais jurídicos sobre o abuso sexual infantojuvenil, ancorada na Teoria do Núcleo Central das Representações Sociais. A amostra foi composta por 31 profissionais, os quais são responsáveis por concretizar políticas públicas com a vítima, a familia e o agressor. Utilizou-se de um questionário sociodemográfico e da Técnica de Associação Livre de Palavras, cujos os dados foram analisados com auxílio dos softwares Statistical Package for the Social Sciences e Interface de R pour les Analyses Multidimensionnelles de Textes et de Questionnaires, respectivamente. Constatou-se que os profissionais têm como núcleo central de suas representações a violência, o trauma e a tristeza, patologizando a figura do abusador, ancorando suas representações em explicações criminológicas e psicológicas do fenômeno. Há uma visão fragmentada da questão, não tecendo explicações macrossociais que abarquem fatores culturais e sociais, nem propostas que envolvam a sociedade como um todo.

Palavras-chave: Adolescente; Criança; Abuso sexual; Representação social.

Violence is an ancient phenomenon that has been prevalent throughout the history of humanity, affecting both children and adolescents. Violence can assume many forms such as neglect as well as physical, psychological, and sexual violence. It can cause physical and psychological harm and prejudice the victim's development and maturation (Maria, 2012; Rates, Melo, Mascarenhas, \& Malta, 2015; Santos \& Yakuwa, 2015). Although it has existed throughout history, violence committed against children and adolescents has only recently been discussed in terms of a universal problem that silently and secretly affects thousands of victims (Florentino, 2015).

The current study focuses on sexual violence, which, as Maria (2012) rightly stated, is a set of actions that go beyond the "merely" sexual and related to other forms of violence such as emotional violence, neglect, and physical violence. Specifically, the current study is exclusively related to situations in which the victim is a child or adolescent because we are considering the growing issue of child and adolescent Sexual Abuse (SA).

As Waiselfisz (2012) noted, approximately 10.425 new cases of child SA were reported in 2011. Although Ordinance No. 1968/2001 of the Ministry of Health makes the reporting of suspected or confirmed cases of abuse against children and adolescents compulsory on the part of health facility professionals within the Unified Health System (SUS, Sistema Único de Saúde), these figures fall short of reality because, in most cases, the facts are not recognized, diagnosed, or reported.

Florentino (2015) defined child and adolescent sexual violence as "acts committed with a sexual purpose that are harmful to the body and mind of the violated [child and adolescent], [and] disregard individual rights and guarantees such as the freedom, respect, and dignity provided by the Children's and Adolescents' Statute" (p. 139). Likewise, we define sexual violence as a trespass against the freedom, sexuality, and basic rights of children and adolescents. Therefore, it is considered a violation against the body, soul, and human rights.

All sexual activity involving children or adolescents is considered sexual violence, regardless of whether it involves physical violence or financial remuneration, when it is practiced by an adult or an individual in a position of power over the victim. Sexual violence can occur via a sexual interaction, petting, genital touching, fellatio, vaginal or anal penetration, voyeurism, pornography, and others (Catarino \& Almeida, 2018; Espindola \& Batista, 2013; Lima, Alberto, Santos, Brito, \& Silva, 2014).

Sexual violence against children and adolescents is divided into SA and the Sexual Exploitation of Children and Adolescents (SECA). The main difference between these modalities is the commercial character of SECA, i.e., in this type of violence, children and adolescents are considered commercial and sexual objects and exploited via pornography, trafficking, sex tourism, and/or prostitution (Florentino, 2015; Lima et al., 2014; Pincolini \& Hutz, 2014). On the other hand, child and adolescent SA includes acts or sexual activities aimed at obtaining the sexual satisfaction of an adult or older adolescent perpetrated against children or

2 adolescents (Florentino, 2015; Lima et al., 2014; Pincolini \& Hutz, 2014). 
Sexual abuse is often one of the most harmful forms of violence against children and adolescents because it includes other forms of violence within a single action. In addition, it has serious implications and affects the victim's development in various ways, causing emotional, social, and psychological damage (Espindola \& Batista, 2013). Regarding the types of sexual abuse, it is possible to distinguish between intrafamily abuse (which includes cases where the abuser has a relationship with the victim, including a consanguineous tie) and extrafamilial abuse (which occurs outside the family environment and involves situations where the perpetrator is a stranger) (Pereira, Conceição, \& Borges, 2018).

A key issue related to child and adolescent SA is the network of protection of these victims' rights, which includes bodies such as the Specialized Police Protection for Children and Adolescents (DEPCA, Delegacia Especializada de Proteção à Criança e ao Adolescente), the Guardianship Councils for Children and Adolescents (CTCA, Conselhos Tutelares da Criança e Adolescente), and the Medico-Legal Institute (IML, Instituto Médico-Legal) and its branches (Lima, 2012). Habigzang, Koller, Azevedo, and Machado (2005) highlighted several social, institutional, and legal factors that tend to delay the application of protective measures for victims and emphasized the fragmented and disjointed character of this network. Likewise, Lima (2012) suggested that all areas should be involved and connected so that care policies can be implemented satisfactorily; furthermore, this author emphasized the connection with policies concerning the fight against impunity and the social rehabilitation of the offender.

According to Pietro, Yunes, and Mattar (2008), child and adolescent protection depends on the knowledge that public bodies, including the Guardianship Council, Public Prosecutor, Police, and Judiciary, have on the subject. As such, a need exists for more scientific-based qualitative knowledge about SA. Pelisoli and Dell'Aglio (2015) noted that because of the objectivity in the application of laws addressing this subject, legal professionals lack a greater understanding about the complexity of this phenomenon, the context in which it appears, and the connections among the victim, family, institutions, and the community as a whole. Habigzang et al. (2005) emphasized that in many cases, this lack of knowledge might lead to the revictimization of the child or adolescent and to the possibility that the network itself promotes additional damage.

To address this lack of knowledge and minimize damage, a legislative movement emerged that led to the approval of Law No. 13.431/2017 (Lei do Depoimento Sem Dano ou do Depoimento Especial [Law of Testimony Without Harm or Special Testimony]) (Presidência da República, 2017). This law observes the importance of the multidisciplinary team within the legal process, the functions of which are described in the Children's and Adolescents' Statute (Presidência da República,1990), which states that it should "... provide input in writing through reports or orally at the hearing, and provide counseling, guidance, referral, prevention, and other work under direct subordination to the judicial authority to ensure the free expression of the technical point of view" (art. 151, Lei $n^{\circ}$. 8.069, 1990). This law seeks to provide a scientific basis upon which a judge can base his or her decision.

Despite the development of special testimony to prevent or reduce revictimization, flaws remain in the application of this methodology. The most important is the lack of professional training. In light of the need to expand the knowledge of the professionals working on policies concerning the prevention and suppression of child and adolescent SA, it is important to study the issue with regard to Social Representation Theory (SRT).

Social Representation Theory describes a development that is socially and collectively performed to guide social actors in the understanding, transformation, and naming of the social world, establish the relationship between the internal and external worlds that humans inhabit, and affect the understanding of its reality (Mafra \& Santos, 2013; Souza, Figueiredo, \& Del Priore, 2015). Silva, Camargo, and Padilla (2011) noted that it is possible for a researcher to grasp the participants' interpretation of the reality of a phenomenon being researched, i.e., to capture the attitudes and behaviors that a certain group has about a certain social 
object. In the case of the current study, that object is psychosocial professionals' social representations of child and adolescent SA.

Moscovici (1978) viewed the conception of representations as a set of concepts, propositions, and explanations created in everyday life over the course of interindividual communication; anchoring and objectification represent the means through which these representations are constituted. Objectification is the way in which a concept is implemented, whereas anchoring concerns the changing of a concept or object into something familiar to the person (Moscovici, 2005). Abric (1993) delineated the functions of representation well, dividing them into a) the knowledge function, which allows a person to grasp and explain reality through the construction of new concepts and knowledge; b) the identity function, in which the individual develops a social and individual identity to locate his or her self in the social field; c) the guidance function, which guides the individual's behavior; and d) the justifying function, which retrospectively justifies behavior and decision making.

This study uses SRT as support for the approach proposed by Jean-Claude Abric (i.e., CCT, Central Core Theory), which seeks to explain representations based on cores that are central or peripheral. Chaves and Silva (2013) defined the central core as a harmonious, rigid, and stable system connected to the collective history of a group and that is therefore consensual. It has the function of organizing, unifying, and stabilizing social and generating representations to modify the forming elements of a social representation. The peripheral core, however, is subject to change and not rigid; it includes contexts, individual experiences, and stories, thereby comprising the group's heterogeneity.

This article aims to identify the structure of the social representations of child and adolescent SA based on the representations of judges (first and second instances) and psychosocial professionals (psychologists and social workers). These professionals were chosen because they deal directly with the resolution of numerous legal situations and their practices might somewhat be affected by the representations that they have of the subject, thereby reflecting the state's response to the investigated phenomenon.

\section{Method}

\section{Participants}

This field research used a mixed (qualitative and quantitative) approach and was conducted at legal institutions in a capital city of Northeast Brazil. The study included 31 male and female legal professionals: 12 magistrates (first- and second-instance judges) and 19 psychosocial professionals (psychologists and social workers). The study included only participants who were working or had worked on cases involving child and adolescent SA and who worked or had worked at a legal institution.

\section{Instruments and data analysis}

A sociodemographic questionnaire was used to characterize the sample, and free word association was applied using the stimulus "child and adolescent SA." The demographic data were summarized as descriptive statistics (frequencies and percentages) calculated using Statistical Package for the Social Sciences 21.0, and the free word association data were analyzed via prototypical and similarity analyses (Camargo \& Justo, 2013) using the R Interface for Multidimensional Analyses of Texts and Questionnaires 4 (IRAMUTEQ). 


\section{Ethical and data collection protocol}

This research met the provisions of Resolution No. 510 of April 7, 2016 of the National Health Council, which outlines the guidelines and regulatory standards for human-subjects research. It was also submitted to the ethics committee of the Universidade Federal da Paraiba (UFPB, Federal University of Paraiba) and approved under CAAE: 49371915.1.0000.5188. Scheduled interviews were conducted in the participants' working environments; these interviews adhered to all ethical standards. Data were collected using a portable voice recorder. The participants' authorization was obtained using a Terms of Free and Informed Consent document to ensure their confidentiality and anonymity.

\section{Results and Discussion}

\section{Sample characteristics}

A total of $64.5 \%$ of the sample were women. This predominance of females was caused by the imbalance of psychology and social care professionals, given that only three of the 12 judges who participated in the study were women. These data show that men remain predominant in the Paraiba Court of Justice.

Those aged 47 to 57 years old constituted the largest age group, representing $35.6 \%$ of the sample. The sample was also composed of middle-aged adults with professional experience: $48.4 \%$ of the participants had worked in their field for over 11 years. Importantly, the age range of the sample was 25 to 68 years old (Mean $=46, S D=12.47$ ), which explains the high standard deviation. Furthermore, the sample was composed of psychologists (41.9\%), social workers (19.4\%), and first- and second-instance judges (38.7\%).

\section{Prototypical analysis}

To identify the structure of the social representations of child and adolescent SA, free word association was used with the stimulus phrase "child and adolescent SA" ("abuso sexual infantojuvenil") to describe the core and peripheral constituents of these representations. First, a database was created using Excel. These data were analyzed using IRAMUTEQ to produce a figure with four quadrants for the given stimulus (Tabela1) containing the words evoked, their Frequency (F), and the Mean Rank of Evocation (MRE).

Tabela 1 was generated using IRAMUTEQ and produced based on evocations with a frequency equal to, greater than, or less than 13, with an MRE of approximately 2.88. Importantly, there were no omissions, resulting in 155 evocations. These evocations were grouped based on lemmatization and semantic procedures. The cutoff for the inclusion of words was 3.

As Tabela 1 shows, the occurrence data are divided into four quadrants that display the central core, the near peripheral systems, contrast elements, and distant peripheral systems of a representation. The left upper quadrant of Tabela 1 (i.e., the central core) contains the evocations with the highest frequencies and lowest MREs (i.e., those that were mentioned most often among the first three words evoked). This quadrant contains the words "violence", "vulnerability", "trauma", and "sorrow"; these terms are unifying and stabilizing elements of the social representation of child and adolescent SA because according to Abric (2001), the central core has a normative essence and is determined by the historical and ideological conditions responsible for the continuity, consistency, and permanence of the representation.

The object of interest in this study is represented in society by the concept of the victim as a vulnerable individual, marked by trauma and wrapped in feelings of sadness. This finding corroborates the work of 
Quadrant of evocations in response to the stimulus of child and adolescent Sexual Abuse

\begin{tabular}{|c|c|c|c|c|c|}
\hline \multicolumn{3}{|c|}{ Central Core } & \multicolumn{3}{|c|}{ Proximal/Peripheral Core } \\
\hline \multicolumn{3}{|c|}{$\mathrm{F}>5.36 \mathrm{MRE} \leq 2.88$} & \multicolumn{3}{|c|}{$\mathrm{F}>5.36 \mathrm{MRE}>2.88$} \\
\hline Evocation & $\mathrm{F}$ & MRE & Evocation & $\mathrm{F}$ & MRE \\
\hline Violence & 13 & 2.5 & Disease & 9 & 2.9 \\
\hline Vulnerability & 10 & 2.6 & Crime & 8 & 2.9 \\
\hline Trauma & 9 & 2.8 & Disgust & 7 & 2.9 \\
\hline Sadness & 8 & 2.6 & Treatment & 7 & 3.9 \\
\hline \multicolumn{3}{|c|}{ Contrast Elements } & \multicolumn{3}{|c|}{ Distal Peripheral System } \\
\hline \multicolumn{3}{|c|}{$\mathrm{F}<5.36 \mathrm{MRE} \leq 2.88$} & \multicolumn{3}{|c|}{$\mathrm{F}<5.36 \mathrm{MRE}>2.88$} \\
\hline Evocation & $\mathrm{F}$ & MRE & Evocation & $\mathrm{F}$ & MRE \\
\hline Fear & 5 & 2.8 & Family & 5 & 3.2 \\
\hline Intrafamily & 5 & 2.6 & Animalistic & 5 & 3.0 \\
\hline Child & 3 & 1.0 & Punishment & 4 & 4.8 \\
\hline \multirow[t]{2}{*}{ Adolescent } & 3 & 1.7 & Impunity & 4 & 4.2 \\
\hline & & & Anxiety & 3 & 4.0 \\
\hline
\end{tabular}

Note: F: Frequency; MRE: Mean Rank of Evocation.

Santos (2011) and Florentino (2015). Furthermore, it emphasizes the latter article, which noted that trauma is the core of child and adolescent SA.

Eloy (2012) indicated that the representation of child SA is often anchored by medical references such as the physical and psychological symptoms presented based on physical evidence of violence to the body and mind; therefore, legal professionals seek medical exams and psychological reports. However, this evidence is not always present because sexual approaches can be diverse. Freitas and Soares (2013) discuss child SA in modern society in the context of a violent nature: "... as the child takes the role of a citizen in development..., it is understood that his [or her] physical and mental development should be protected from any violence that might interfere in this process and that can have serious consequences" (p. 1). The findings of the current study suggest that the participants' social representations also include the idea that child and adolescent SA is always a physically violent act, even though the literature often notes that it does not always involve physical violence. For example, the presence of psychological violence via threat and coercion is possible (Florentino, 2015; Justino et al., 2015; Santos \& Yakuwa, 2015).

The word "vulnerability" likely emerged because we are addressing children and adolescents who (according to the literature) are considered vulnerable and immature individuals and likely to be easily tricked by adults (Arpini, Siqueira, \& Savegnago, 2012). Child and adolescent SA is classified as a hideous crime given its great social disapproval. The law provides for significant punishment as well as difficulty in obtaining prison benefits, given the representation of vulnerability anchored by Brazilian law, in particular in the structure of the standards observed in the Penal Code and the Statute of Children and Adolescents.

The near peripheral system is indispensable to the central core because it is responsible for the protection, upgrading, and contextualization of its regulatory mandates and the configuration of social representations (Chaves \& Silva, 2013; Machado \& Aniceto, 2010). The following evocations were found in the proximal peripheral system: "disease", "crime", "disgust", and "treatment". We believe that the term 6 "disease" is directly related to the abuser, who is considered a person with a disorder. This association was 
also found in Santos (2011) study. The terms "crime" and "disgust" were evoked because SA is an illegal act that generates negative feelings among professionals, reinforcing the idea that it is a crime, an act of rule breaking, and therefore punishable. These data corroborate those found by Santos (2011).

The term "treatment" took two forms: that of the victim and that of the offender. In this regard, although we know about the importance of treatment given the literature, it is difficult to act appropriately in these cases both for structural reasons and due to limitations in the professional training of those working in the healthcare system (Ávila, Oliveira, \& Silva, 2015). Santos (2011) noted that the punishment of the offender does not imply an impediment to the treatment of this individual. Moreover, treatment does not negate the victim's rights; rather, it is done to minimize future attempts to reoffend.

In the contrast elements and distal peripheral system, which act as a link between the central system and concrete reality according to Abric (1996), the words evoked for the former were "fear", "intrafamily", "child", and "adolescent"; the words for the latter were "family", "animalistic", "punishment", "impunity", and "anxiety". We emphasize the words "fear", "intrafamily", and "family" because child and adolescent SA perpetrated by family members is traumatic and harmful to the psychological and social development of the victim; its complex dynamics breach trust and break emotional ties (Said, Junqueira, \& Costa, 2016).

Several authors have noted that intrafamily child and adolescent SA is the most frequent form (Baía, Veloso, Magalhães, \& Dell'Aglio, 2013; Gava, Silva, \& Dell'Aglio, 2013; Justino et al., 2015; Oliveira, 2013; Soares et al., 2016), which might be counterintuitive because the family should act as a safe haven for its members, not as an unsafe environment, full of suspicion, fear, and uncertainty. A role reversal takes place when the aggressor places a child or adolescent in the position of a sexual partner, thereby changing the roles of family members and decharacterizing the family group as a safe environment, causing fear of the abuser and damage to these victims' development (Florentino, 2015). We performed a similarity analysis to more deeply explore how the "profession" variable affected the studied sample's representations.

\section{Similarity analysis}

The similarity analysis was based on graph theory, a branch of mathematics that examines the relationships among the objects of a given set (Marchand \& Ratinaud, 2012). This analysis enables the identification of co-occurrences among words, and the results express the connectivity among words. Co-occurrences are represented by the numbers that appear above the connecting lines; higher line values represent stronger connections between words (Figure 1). These words are presented in the discussion, along with the words evoked within parentheses.

For this analysis, the profession variable was used, dividing the corpus into two groups: "psycholsocials" (i.e., social workers and psychologists) and "judges" (i.e., first- and second-instance magistrates). This type of analysis enables a deeper consideration of the evoked words previously analyzed in the prototypical analysis and allows for observations of between-group differences. The approximations and differences related to the studied groups can then be discussed, how each group represents child and adolescent SA can be analyzed, and which social representations are associated with which professions can be considered.

The similarity analysis revealed that the word "trauma" was common to both professional groups and was a central element and organizer of the representation. In addition, the terms more closely related to criminality and the pathologization of the abuser such as "disease" (6), "crime" (5), "disgust" (4), and "animalistic" (4) were linked to morality issues.

Importantly, the belief that the abuser is a person who differs from those considered normal comes from the participants' descriptions of these people as "sick and animalistic" who engage in acts that go beyond what is considered socially normal. Likewise, Freitas and Soares (2013) noted that this pathologizing 


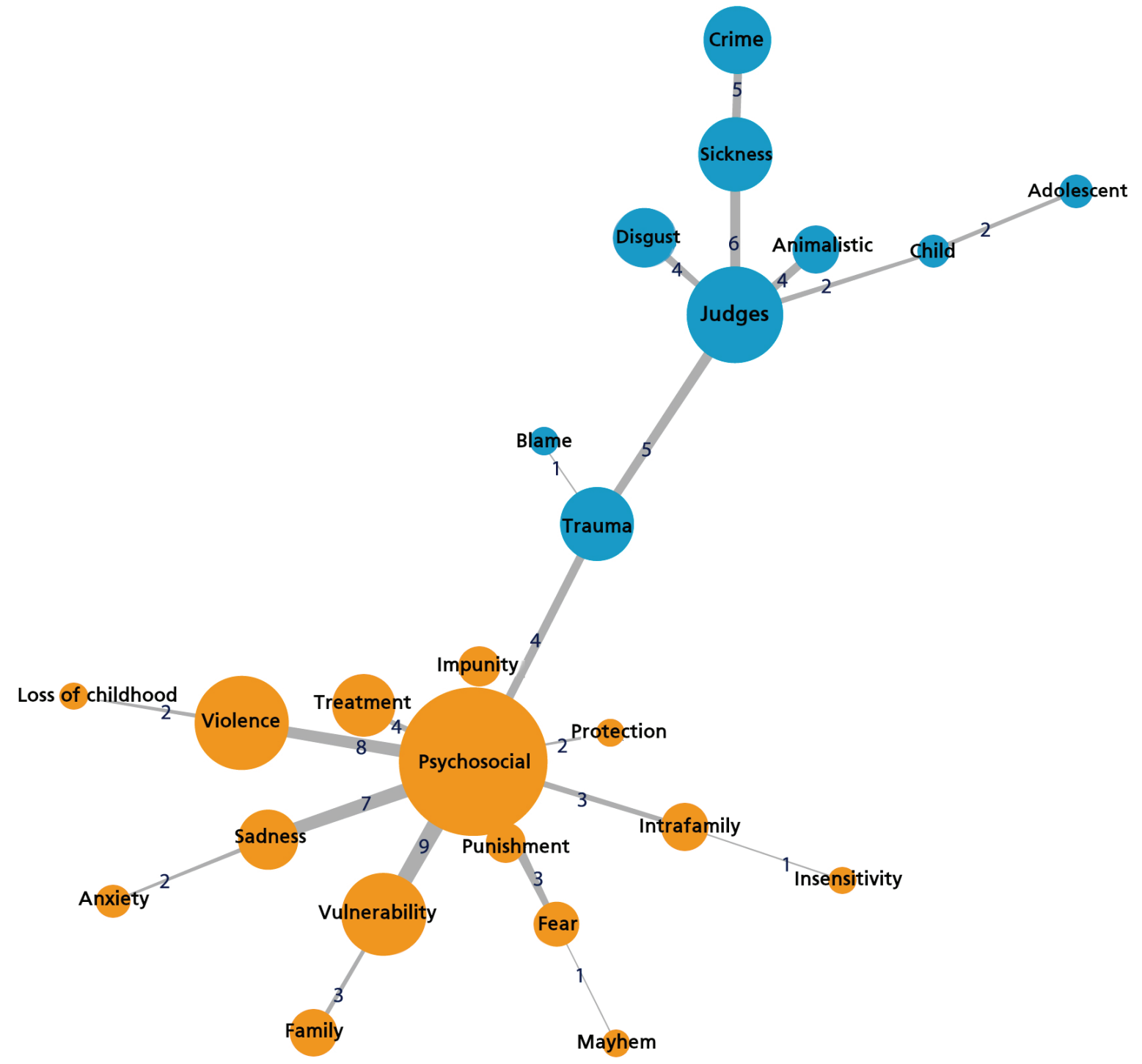

Figure 1. Chart analyzing the similarity of the child and adolescent SA stimulus by profession.

focus represented by the indication of a disorder or unusual characteristic does not question society with regard to the production of these people; rather, reflections are reduced to issues that are purely subjective, generalizing, and moralist. The authors further assert that a crucial factor for an analysis of sexual violence is omitted but present in their concrete manifestation "...in a power imbalance exerted by an adult over a child or adolescent during a process of appropriation and domination of the other" (Freitas \& Soares, 2013, p.3). They also emphasized the pressing need for the demystification of perpetrators of sexual violence because they are found across all social, ethnic, and age groups. A critical view is needed regarding the relationships among domination, discrimination, and exploitation that continue to exist in society. Esber (2010) confirmed the need to demystify aggressors, emphasizing that they are not "weird" or "crazy", nor can they be identified by aspects of physiognomy. They 8 include individuals who originate from all social classes, ethnic groups, and ages. 
For the judges, the evocation of the word "crime" was linked to the objective of their professional category (where the aggressor is criminally responsible, thereby meeting the objective definitions of criminal law) because these professionals are responsible for interpreting social behavior and framing it within the abstract provisions of the law, establishing punishments, and revealing the inappropriateness of the individual and his or her relationship with society. The judges associated the abuser with the words "sick", "disgust", and "animalistic." However, Fazenda (2016), citing Leyens (1985), noted that it is a "fundamental error" to attribute SA to the abuser's characteristics. Relations to a character trait originated from implicit personality theory.

Conversely, psychosocial professionals more often evoked the term "vulnerability" (8), which was linked to the term "family" (3). Rather than connecting the family to the treatment and care of child victims of abuse, this association considers family a vulnerability factor. These professionals also used the terms "intrafamily" and "insensitivity", which further indicates their concern with the family as the place where abuse occurs.

The term "violence" (8) was significant among the psychosocial professionals, signifying these professionals' concerns with the consequences of abuse for the victim. This concern introduces associated terms such as "loss of childhood" (2), "sadness" (7), "anxiety" (2), "fear", and "mayhem". The psychosocial professionals anchored their representations of abuse by psychosocial issues; however, their explanations were based more on a microsocial perspective linked to the family and victim than on a deep social analysis of SA. Psychosocial professionals also used the word "treatment" (4) to emphasize the importance of psychotherapeutic treatment to monitor abuse victims, given the focus on their suffering. Importantly, the evocation of the terms "protection" and "punishment" should be highlighted because they demonstrate the concern and care that these professionals have for SA and the victim; furthermore, they demonstrate a concern for the legal area when evoking the word "impunity".

In general, the social representations of child and adolescent SA remain individualized and based on the pathologization and culpability of the offender. They are revealed by excluding the practices of punishment (criminality) or treatment. The participants also had a fragmented view (i.e., without shared representations). This finding suggests that each professional has a limited notion of the phenomenon, rooted in their original training, without a link to knowledge and the inability to create wider explanations that address macrosocial issues. Therefore, a more structured action is lacking, with wider interventions involving the state, society as a whole, the victim, the family, and the professionals involved to understand that SA is a phenomenon multidetermined by the confluence of individual, social, and cultural factors. Such representations tend to undermine work on SA because a need exists for interventions in terms of both primary and tertiary prevention. This way of representing the phenomenon is insufficient when trying to understand its complexity, which should encompass the family, institutions, and broader social networks.

\section{Final Considerations}

The participants in the current analyses were well positioned with respect to the proposed theme based on the knowledge that they have acquired from their academic backgrounds, practical performance, and perceptions arising from common sense. Thus, they built social and personal identities that ultimately guide them in their decision making (judges) or their way of acting toward the victim, the victim's family, and the abuser (psychologists and social workers).

We are aware of the need for further investigations to address issues that remain beyond the scope of the current study. Research with other professionals working in the area should also be conducted because understanding how they think might enable us to understand how they act. This knowledge would expand the goals of the current study and deepen our understanding of SA. We hope that this work will help support 
the appropriate execution of public policies regarding harm prevention among victims and allow policies to be implemented that help legal professionals consider child and adolescent SA. It should also serve to minimize the limited and stigmatizing representations concerning this issue and provide information to reduce revictimization in court proceedings and the pathologization of the abuser. Ultimately, it should promote interventions that appropriately represent the victim, their family, and the aggressor.

\section{Contributiors}

C. A. PEREIRA contributed to the design, drawing, writing, analysis and aproval of the final version of this article. S. C. MACIEL contributed analysis and interpretation of data, orientation in the article elaboration. D. B. SILVA and L. M. F. MELO contributed in the analysis of the results, helping to systematize them.

\section{References}

Abric, J. C. (1993). Central system, peripheral system: their functions and roles in the dynamics of social representations. Papers on Social Representations, 2(2), 75-78.

Abric, J. C. (1996). Specific processes of social representations. Papers on social representations, 5(1), 77-80.

Abric, J. C. (2001). O estudo experimental das representações sociais. In D. Jodelet (Org.), As Representações Sociais (pp.155-172). Rio de Janeiro: UERJ.

Arpini, D. M., Siqueira, A. C., \& Savegnago, S. D. O. (2012). Trauma psíquico e abuso sexual: o olhar de meninas em situação de vulnerabilidade. Psicologia: Teoria e Prática, 14(2), 88-101. Recuperado em julho 6, 2018, de http:// editorarevistas.mackenzie.br/index.php/ptp/article/view/3263/3 673

Ávila, J. A., Oliveira, A. M. N., \& Silva, P. A. (2015). Abuso sexual contra crianças e adolescentes: estudo com enfermeiros da estratégia de saúde da família. VITTALLE: Revista de Ciências da Saúde, 24(2), 43-52. http://dx.doi.org/10.14295/ vittalle.v24i2.5130

Baía, P. A. D., Veloso, M. M. X., Magalhães, C. M. C., \& Dell'Aglio, D. D. (2013). Caracterização da revelação do abuso sexual de crianças e adolescentes: negação, retratação e fatores associados. Temas em Psicologia, 21(1), 193-202. http://dx.doi.org/10.9788/TP2013.1-14

Camargo, B. V., \& Justo, A. M. (2013). IRAMUTEQ: um software gratuito para análise de dados textuais. Temas em Psicologia, 21(2), 513-518. http://dx.doi.org/10.9788/TP2013.2-16

Catarino, E. M., \& Almeida, M. P. (2018). A importância do professor da educação infantil no combate a violência sexual infantil. Anais do Colóquio Estadual de Pesquisa Multidisciplinar. Goiás. Recuperado em julho 6, 2018, de http:// publicacoes.unifimes.edu.br/index.php/coloquio/article/view/344

Chaves, A. M., \& Silva, P. L. (2013). Representações sociais. In L. Camino, A. R. R. Torres, M. E. O. Lima, \& M. E. Pereira (Orgs.), Psicologia social: temas e teorias (pp.411-464). Brasília: Technopolitik.

Eloy, C. B. (2012). Psicologia e direito: um diálogo possível nos casos de abuso sexual na infância (Tese de doutorado não-publicada). Universidade Estadual Paulista, Assis. Recuperado em dezembro 27, 2018, de https://repositorio. unesp.br/ bitstream/handle/11449/105595/eloy_cb_dr_assis.pdf?sequence=1\&isAllowed=y

Esber, K. M. (2010). Autores de violência sexual contra crianças e adolescentes. Goiânia: Cânone Editora.

Espindola, G. A., \& Batista, V. (2013). Abuso sexual infanto-juvenil: a atuação do programa sentinela na cidade de Blumenau/SC. Psicologia: Ciência e Profissão, 33(3), 596-611. Recuperado em julho 6, 2018, de http://www.redalyc. org/articulo.oa?id=282028779007

Fazenda, I. (2016). Representações sociais do abuso sexual de crianças numa amostra de médicos e enfermeiros dos cuidados de saúde primários. In M. J. Quartilho, H. Almeida, I. Fazenda, I. Gil, L. Fernandes, M. F. Sousa, ... R. Alcaire, Cadernos de psiquiatria social e cultural (pp.95-111). Coimbra: Imprensa da Universidade de Coimbra. http://dx.doi. org/10.14195/978-989-26-0968-3_5

Florentino, B. R. B. (2015). As possíveis consequências do abuso sexual praticado contra crianças e adolescentes. Fractal: Revista de Psicologia, 27(2), 139-144. http://dx.doi.org/10.1590/1984-0292/805

Freitas, S. B., \& Soares, A. C. N. (2013). Autores de violência sexual contra crianças e adolescentes, gênero e representações sociais: uma reflexão necessária. Seminário Internacional Fazendo Gênero, Florianópolis. Recuperado em dezembro 
27, 2018, de http://www.fg2013.wwc2017.eventos.dype.com.br/resources/anais/20/ 1372868332_ARQUIVO_artigo_ fazendo_genero_Solange.pdf

Gava, L. L., Silva, D. G., \& Dell'Aglio, D. D. (2013). Sintomas e quadros psicopatológicos identificados nas perícias em situações de abuso sexual infanto-juvenil. Psico, 44(2). Recuperado em julho 6, 2018, de https://dialnet.unirioja.es/ servlet/articulo?codigo $=5631473$

Habigzang, L. F., Koller, S. H., Azevedo, G. A., \& Machado P. X. (2005). Abuso sexual infantil e dinâmica familiar: aspectos observados em processos jurídicos. Psicologia: Teoria e Pesquisa, 21(3), 341-348. http://dx.doi.org/10.1590/S0102-37 722005000300011

Justino, L. C. L., Nunes, C. B., Gerk, M. A. D. S., Fonseca, S. S. O., Ribeiro, A. A., \& Paranhos Filho, A. C. (2015). Sexual violence against adolescents in Campo Grande, Mato Grosso do Sul, Brazil. Revista Gaúcha de Enfermagem, 36(Special issue), 239-246. http://dx.doi.org/10.1590/1983-1447.2015.esp.56820

Leyens, J. (1985). Teoria da personalidade na dinâmica social. Lisboa: Biblioteca Verbo.

Lima, J. A. (2012). A repetição do abuso sexual intrafamiliar infanto-juvenil entre gerações (Tese de doutorado não-publicada). Universidade Federal da Paraíba, João Pessoa. Recuperado em dezembro 28, 2018, de http://tede. biblioteca.ufpb.br:8080/handle/tede/6901

Lima, J. W. D., Alberto, M. D. F. P., Santos, V. M. D., Brito, K. L., \& Silva, S. L. G. (2014). Violência sexual infantojuvenil: o que dizem os documentos do juizado? Estudos Interdisciplinares em Psicologia, 5(1), 2-24. http://dx.doi.org/10.5433/223 6-6407.2014v5n1p2

Machado, L. B., \& Aniceto, R. D. A. (2010). Núcleo central e periferia das representações sociais de ciclos de aprendizagem entre professores. Ensaio: Avaliação e Políticas Públicas em Educação, 18(67), 345-363. Recuperado em julho 6, 2018, de http://www.redalyc.org/html/3995/399537970009/

Mafra, V. C. A. S., \& Santos, M. D. F. S. (2013). Do novo ao tradicional: a representação da psicologia no judiciário. Estudos e Pesquisas em Psicologia, 13(2). Recuperado em julho 6, 2018, de http://www.redalyc.org/html/4518/451844511009/

Marchand, P., \& Ratinaud, P. (2012). L'analyse de similitude appliquée aux corpus textuels: les primaires socialistes pour l'élection présidentielle française (septembre-octobre 2011). Actes des 11eme Journées internationales d'Analyse statistique des Données Textuelles-JADT, Bruxeles, pp.687-699. Récupéré dans Décember 28, 2018, from http://lexicometrica.univ-paris3.fr/jadt/jadt2012/Communications/Marchand,\%20Pascal\% 20et\%20al.\%20-\%20 L'analyse\%20de\%20similitude\%20appliquee\%20aux\%20corpus\% 20textuels.pdf

Maria, S. G. D. S. (2012). Abusos sexuais de crianças: mudanças resultantes de uma intervenção preventiva (Tese de doutorado não-publicada). Instituto Universitário de Ciências Psicológicas, Sociais e da Vida, Lisboa. Recuperado em julho 6, 2018, de http://hdl.handle.net/10400.12/1768

Moscovici, S. (1978). A representação social da psicanálise. Rio de Janeiro: Zahar.

Moscovici, S. (2005). Memória, imaginário e representações sociais. Rio de Janeiro: Museu da República Editora.

Oliveira, C. A. (2013). Abuso sexual no contexto da sociedade atual e suas representações. Diálogos Multidisciplinares, 1(3). Recuperado em julho 6, 2018, de http://revista.faculdadeguarapuava.edu.br/index.php/Revistafg2/article/ view/82

Pelisoli, C. L., \& Dell'Aglio, D. D. (2015). Práticas de profissionais de Psicologia em situações de abuso sexual. Arquivos Brasileiros de Psicologia, 67(1), 51-67. Recuperado em julho 6, 2018, de http://seer.psicologia.ufrj.br/index.php/abp/ article/view/885

Pereira, A. B. M., Conceição, M. I. G., \& Borges, L. F. F. (2018). Reflexões sobre formação de professores para o enfrentamento da violência intrafamiliar contra crianças. Tecnia, 2(2), 63-83. Recuperado em julho 6, 2018, de http:// revistas.ifg.edu.br/tecnia/article/view/145

Pietro, T., Yunes, A., Mattar, M. A. (2008). Considerações jurídicas e psicossociais sobre o abuso sexual contra crianças e adolescentes. Âmbito Jurídico, (58). Recuperado em maio 14, 2015, de http://www.ambito-juridico.com.br/site/ index.php?n_link=artigos_leitura_pdf\&artigo_id=4021

Pincolini, A. M. F., \& Hutz, C. S. (2014). Abusadores sexuais adultos e adolescentes no sul do Brasil: pesquisa em denúncias e sentenças judiciais. Temas em Psicologia, 22(2). Recuperado em dezembro 13, 2015, de http://pepsic.bvsalud.org/ scielo.php?script=sci_arttext\&pid=S1413-389X2014000200004\&lng=pt\&nrm=iso>

Presidência da República (Brasil). (1990). Lei n 8.069, de 13 de julho de 1990. Dispõe sobre o Estatuto da Criança e do Adolescente e dá outras providências. Recuperado em dezembro 28, 2018, de http://www.planalto.gov.br/Ccivil_03/ leis/L8069Compilado.htm 
Presidência da República (Brasil). (2017). Lei n 13.431, de 4 de abril de 2017. Estabelece o sistema de garantia de direitos da criança e do adolescente vítima ou testemunha de violência e altera a Lei no 8.069, de 13 de julho de 1990 (Estatuto da Criança e do Adolescente). Recuperado em dezembro 28, 2018, de http://www.planalto.gov.br/ ccivil_03/_Ato2015-2018/2017/Lei/L13431.htm

Rates, S. M. M., Melo, E. M., Mascarenhas, M. D. M., \& Malta, D. C. (2015). Violência infantil: uma análise das notificações compulsórias, Brasil 2011. Ciência e Saúde Coletiva, 20(3), 655-665. http://dx.doi.org/10.1590/1413-81 232015203.15242014

Said, A. P., Junqueira, E. L., \& Costa, L. F. (2016). A passagem ao ato no abuso sexual intrafamiliar fraterno de menino. Revista Brasileira Adolescência e Conflitualidade, (14), 5-12. http://dx. doi.org/10.17921/2176-5626.n14p5-12

Santos, J. S., \& Yakuwa, M. S. (2015). A estratégia saúde da família frente à violência contra crianças: revisão integrativa. Revista da Sociedade Brasileira de Enfermeiros Pediatras, 15(1), 38-43. Recuperado em julho 6, 2018, de http://sobep. org.br/revista/images/stories/pdf-revista/vol15-n1/vol_15_n_2-artigo-de-revisao-2.pdf

Santos, R. D. C. F. D. (2011). Violência sexual e a formação de educadores: uma proposta de intervenção (Dissertação de mestrado não-publicada). Universidade Estadual Paulista, Presidente Prudente. Recuperado em julho 7, 2018, de https://repositorio.unesp.br/handle/11449/92264

Silva, S. É. D., Camargo, B. V., \& Padilha, M. I. (2011). A teoria das representações sociais nas pesquisas da enfermagem brasileira. Revista Brasileira de Enfermagem, 64(5), 947-951. Recuperado em julho 6, 2018, de http://www.redalyc. org/html/2670/267022214021/

Soares, E. M. R., Silva, N. L. L., Matos, M. A. S., Araújo, E. T. H., Silva, L. D. S. R., \& Lago, E. C. (2016). Perfil da violência sexual contra crianças e adolescentes. Revista Interdisciplinar, 9(1), 87-96. Recuperado em julho 7, 2018, de https:// revistainterdisciplinar.uninovafapi. edu.br/index.php/revinter/article/view/754

Souza, A. C., Figueiredo, T. A. M., \& Del Priore, M. (2015). Representações sociais sobre a mulher: um estudo com escolares. Revista ECOS, 10(1). Recuperado em julho 6, 2018, de https://atendimento.unemat.br/index.php/ecos/ article/view/758

Waiselfisz, J. J. (2012). Mapa da violência 2012: crianças e adolescentes do Brasil. Rio de Janeiro: Faculdade Latino-Americana de Ciências Sociais. Recuperado em agosto 1, 2019 de https://www.mapadaviolencia.org.br/ pdf2012/MapaViolencia2012_Criancas_e_Adolescentes.pdf

Receveid: July 18, 2018

Final version: February 5, 2019

Approved: June 17, 2019 